\title{
Learning Strategies and Styles of a Part Time Job Student With Good Achievement (A Case Study of a Successful Part Time Job EFL Learner)
}

\author{
Rigel Sampelolo \\ rigelsampelolo@gmail.com
}

Haryanto Atmowardoyo

aharyanto_fbsunm@yahoo.co.id

State University of Makassar, Indonesia

\begin{abstract}
This research intended to find out the comprehensive description of learning strategies, and styles applied by the part-time job University student at the Christian University of Indonesia Toraja, and all the contributing factors that affect his learning process. The method used in this research was grounded theory. The instruments were an interview, direct observation, and documentation. The participant of the research was the part-time job student academic year 2014/2015 at English Department of Christian university of Indonesia Toraja. The result of the research showed that (i) the learning strategies performed by this student were the direct and indirect strategy. The direct strategy included memory, cognitive, compensation strategies while indirect strategy covered affective and social strategy. (ii) Learning styles perform by this student were visual and kinesthetic style. And (iii) the factors contributing to student's success were Personality, Motivation, English practicing, Social interaction, and Selfmanagement.
\end{abstract}

Keywords: learning strategies, learning styles, contributing factors to learning process, part time job student.

\section{Introduction}

Learning is an active social process in which learners construct new ideas and concepts based on their background knowledge. In the learning process, there are many goals that must be achieved. To attain the goal of the learning, there are many ways that can be applied. Unfortunately, there are still many cases indicated that the students' achievements are still far from expectation. But on the other hand, there are several of the students which can be categorized into success in the learning process. The successful in learning activities is also gained by the part-time job student. In this case, some people assume that the learner who has a part time job will face some difficulties to join the learning process, because as a learner, particularly in an educational institute, focus and good time management are needed in order to gain a good achievement. They also should be cleverly put their time in order. 


\section{2| ELT Worldwide Vol. 3 No.l April 2016}

If they must work, it means that they will not have enough time for studying. If so, they will fail in the university or college. This assumption is not absolutely correct.

As Brown (2002: 4) argues that school environment is not only a place to gain a success in the learning process. Success can be gained by spending a little extra time outside class and practicing our skill and knowledge. Other factors that give contribution for the students' success in learning activities are learning strategies and learning styles (Haryanto: 1999, Reid, 1987; Celce Murcia, 2001). Age, aptitude for languages, motivation, attitude, personality, memory, sex, cognitive style, intelligence, and immersion factors community influence, and family education in primary language are also factors which contribute in learning process (Collier1988, Carrol 1981, Ushioda, 2008:19, Richard, 2005: 286, Zhang 2008: 58, Hannell: 2008: 8, Beeching: 2002: 6 - 9, Leaver, 2005:70, Mahdavi , 2008: 109 - 126, Dunlap and Weisman , 2006: 27).

The research was intended to reveal learning strategies, learning styles and contributing factors that affected the part time job student at the English Department of the Christian University of Indonesia Toraja in his learning activities. Tthe findings of this research may be used to enrich the theory of learning strategies, learning style and contributing factors in learning activities.

\section{Methodology}

A case study was used in this research as a part of the naturalistic design (Anderson \& Arsenault 1998: 121). In analyzing collected data, the researcher applied the grounded theory. A grounded theory design is a systematic, qualitative procedure used to generate a theory that explains, at a broad conceptual level, a process, an action, or an interaction about a substantive topic. The participant of the research named SPR. He was selected through purposive sampling. He was a part-time job University student at English Department the Christian University of Indonesia Toraja who has good achievement in his learning.

This research intended to find out the comprehensive description about learning strategies, learning styles applied by the successful part time job University student and all the contributing factors that affect his success.

There are three major instruments in this research namely: observation, interview and documentation. To collect the data the researcher set some procedures such as interviewed the learner, employed direct observation during the teaching and the learning process of UKIT program, in workplace and learner's home and interviewed some lecturers of English department of UKI Toraja, friends, co-workers and parents/neighbors. 


\section{Result}

Based on the interviews and observations result, the researcher found and categorizing concepts and phenomena related to learning strategy, learning styles, and contributing factors in student's learning process. Those are :

\section{Learning strategy}

Learning strategies were all of the activities that performed by SPR in order to gain, understand and comprehend the knowledge or gain his learning goal. These strategies were not only performed by him on the campus, but it was applied in whole his activities. In this study, the researcher found that there were several learning actions or strategies performed by this student. They are:

\section{Make repetition}

As SPR said that he was difficult to memorize because of his age. Thus, he needed to repeat the lesson again and again,by this way; he would be easier to understand the topic or the lecture he had learned.

I :To remember new information, what do you usually do?

Subject $\quad:$ By repetition again and again. If there any things that I do Not understand well, I would ask my friends and ask the lecturer directly.

I : Why do you do that?

Subject : This is very useful because I have to make repetition. If I do not always continue and repeat what I have studied, it will be easily forgotten.and...So I could get what I did not understand.

\section{Give a sign, writing in the piece of paper}

: Ok, please tell me how do you learn new information?

Subject $\quad$ : The process is that when I learn and acquire new vocabulary, I gave the sign, highlighter, a circle or I rewrite it in a paper or a piece of letter. By that way, I would easily get that this is new information for me.

When SPR wanted to emphasize the lesson or topic that was very important for him, he would give the sign by highlighting the sentences or the topic and when he wanted to memorize something he would write 
94| ELT Worldwide Vol. 3 No.1 April 2016

down the sentences or word on a piece of paper then it would be slipped into his book, hence, when he opened his book he would easier to recognize that the piece of the paper was the sentences or words that would be memorized.

\section{Lowering anxiety}

When SPR in high anxiety situation, for extending when he spoke to the native speaker visitors and the visitors could not understand, He would turn to be calm and speak slowly

I : So how do you reduce the anxiety?

Subject $\quad$ : To reduce it, I usually to be calm, and then I spoke slowly so my encounters can understand that I do need people who speak slowly as well.

\section{Practice to the friends, stranger and asking to the guide}

In increasing his knowledge, SPR did not rely on himself. He still needed some helps from his environment and his friends. When he was in the workplace, and he could not understand what the visitors talked about, he would ask to the visitor's guides. He also practiced his English to his friends and when he met a foreigner at his workplace.

I : What do you do if you need assistance in learning?

Subject : I usually ask to their guide (when at work)

I : How do you practice English outside the classroom?

Subject : I am practicing with my friends then at work I usually use my English to strangers.

\section{Learning style}

There were two ways applied by SPR in order to think, process information, demonstrate learning, and acquire knowledge and skills. Those ways were preference and instrument using.

\section{Preferences}

A preference referred to SPR's preferred in learning without including instrument. SPR believed that he would best learn by involving himself into group such as in group discussion. 

discussing something in groups in class?

Subject : I really like to discuss it with my friends in the group. your friends, aren't you?

Subject : Yes I am.

He also would have better responses if he learned by practicing, such as visiting the particular place that had engaged with the lesson.

How to learn by practicing, do you like?

: How to learn by practicing, do you like?

Subject $\quad$ : Yes I do.

: How to learn by visiting a particular place?

Subject : I like to visit a certain place

Instrumental using.

Using the instrument in acquiring the information also gave contributions to SPR. in this case; the instrument was the things used as a clue or guidance in order to facilitate him in recognizing what he wanted to know. SPR involved some instruments in order to help him in processing, gain, or improve the knowledge surrounding him. Those instruments such as the using of color pencils or highlighter.

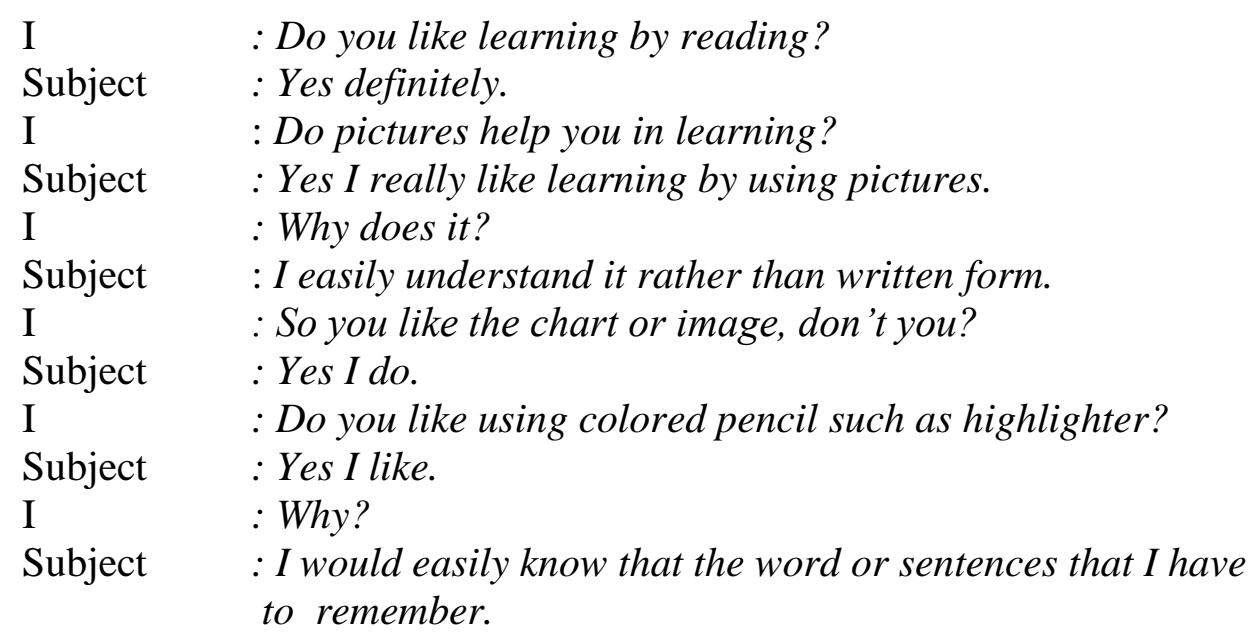


96| ELT Worldwide Vol. 3 No.1 April 2016

He used the colored pencils to highlight the information that was considered important for him. By highlighting, he would be easy to respond that information. He could also easily to concentrate processing the information that displayed by using chart or some pictures

\section{Affecting factors of SPR success}

\section{Personality}

SPR was the extrovert student. It was indicated by his learning actions and his daily lives with his friends, whether it was in campus, home or workplace. It was shown by his activities when performing or interacted with other people. When on campus, particularly in the learning process, SPR was actively in giving some questions to the lecturers. Not only gave some questions but he was also active in answering and responding to the lecturers' questions and gave some opinions when it was needed.

: What about when he is in the classroom is he an active student?

Friends $\quad$ : He is a very active student, of 35 students in the class, he was the most active he would be the first to answer the entire lecture's question, he essentially the most active in the classroom.

As same as in learning process, SPR was also actively involved in study group, When he was in group, he always becomes a leader in that group, and in that position as a group leader, he always encouraged his friends by giving the motivation to finish the task or the job that would be done, he also managed his friends, hence, the group members would do best their function.

I $\quad$ As your remember when teaching, what was he in the class.

Lecturer : During my class, when I observe him, when in the learning process in the classroom, he is quite an intelligent person; he was active in the classroom, either individually or in a group. He gives a lot of contribution when he discussed in a group form, he looked very active in the group.

I : So when working in the group, he is a really active person.

Lecturer : Yes, He pretty much gave the information to his friends in the group to complete the task. 


\section{Motivation}

SPR interested in learning English because he saw that there were many tourists visiting the place where he lived.When SPR come to Toraja, His interested of English was raising. It is caused by the foreigner tourist that visiting this place, $\mathrm{He}$ also saw the opportunity to develop then tourism business.

: What is your main goal of learning English?

Subject $\quad$ : At the beginning I said that vacancy for English is still very good. We can work if only know English well, therefore, I wish to do business in the tourism field. If we do not master a oreign language, then doing business in tourism it would be very difficult.

\section{English Practicing}

English practicing was all of the SPR's chance in performing his English proficiency. His performance his English in order to convey, share, and give some opinions and explanations to everyone who need. Along the researcher's observations and interviews, SPR practiced his English not only in the learning process but also in all his daily activities, such as at home, campus and his workplace. At home, he was practicing his English by teaching his niece English. While in his workplace, because most of the visitors in his workplace were foreigners, he used English as a language to communicate, He practiced his English to greet, over some foods, show the direction or event explain something because of misunderstanding by the visitors such as complaining. When at the campus, he used or practiced his English in the learning process. He used his English to give or comment some questions either from his friends or from the lecturers.

\section{Social interaction}

The interaction included all of the interactions that happened on campus, workplace, and at home. When in the workplace, the relationship of SPR and his friends in the workplace did not only limit at Co - workers relationship, but they have a bunch as a family, SPR could involve interacting with his co-workers and he could also work with the whole employer. When there were not visitors, he joined with his friends to talk. When at home, even though he had limited time at home but he still used his time to hang and talk with friends in his free time. At campus, SPR also preferred to come home with his friends rather than come alone. 
98| ELT Worldwide Vol. 3 No.l April 2016

By coming home with his friends he could share or exchange some ideas. All interactions or activities that had been performed by SPR lead him to the success, not only in his community but in learning process.

\section{Self-management}

The SPR's self-management was his ability to control, manage, behave and make some decisions in his daily activities such as the actives related to his campus, working and even at home. Those activities are Never late to entry the task, Preparing the lesson for the next day, Doing task at the workplace, Study after working, Study in the morning.

\section{Discussion}

This study explored the learning strategies, styles performed by a successful part time job EFl learner and contributing factors that affect this student's success.

Make referenced to the oxford's learning strategy taxonomy (1990) this student performed both direct and indirect strategy. Repetition is a part of the direct strategy. It was the action performed by SPR in order to comprehend somethingRepetitions have an impact on the ways people make meanings. In this respect, Johnstone et al (1994) argued that repetition created a cognitive effect. Repetition helped him to improve speed in acquiring and understanding something new.

Giving a sign and writing the crucial information on a piece of paper was also recognized as a creating structure for input and output the actions which is the part direct strategy (Oxford : $1990: 19$ ). It is reasonable that there was always important information found when reading a notebook or the other resources. To show that the information was helpful, SPR would give the sign; he signed the sentences by using colors. Giving sign was not only showing the important information but it would make easier for him to remember that information. Remembering the information would involve memory. Practicing English to the friends is also part of the direct strategy (Oxford,1999: 19) as a foreigner language learners, practice the previous knowledge is very crucial. SPR benefited from practice because he was able to apply knowledge through interaction. When he practiced using the knowledge through an application, he connected with information on a deeper level.

In indirect strategies, turning to be calm and speak slowly were the sets of strategies that SPR performed in his learning approaches. Turning to be calm and speak slowly were the ways he did to reduce his anxiety during the speaking process. 
Sampelolo, Atmowardoyo : Learning Strategies and Styles of ...

Language learning anxiety constitutes a specific kind of anxiety, aroused by situational factors such as tests, speaking in front of class, and being called on by the teacher (Horwitz, \& Cope: 1986; Macintyre \& Gardner: 1989, 1991 in Sheen).

His anxiety during the speaking process was normally feelings. Reference to MacIntyre \& Gardner,1994:284 ), SPR's anxiety has been labeled as Foreign language anxiety (FLA) and has been defined as all of the feelings of tension and apprehension specifically related to second language contexts, which include speaking, listening, and learning. This FLA commonly develops in the foreign language learning.

In order to reduce his anxiety, SPR applied the techniques. It was applied in order to set his mind at a rest so he could think clearly and know what would be done. It was supported by Seo et al. (2004: 430) that showed people in positive feeling states are more likely to focus on exploring and obtaining anticipated positive outcomes.

\section{Learning styles}

Brown (2000) defines learning styles as the manner in which individuals perceive and process information in learning situations. Leaver (1998) divided learning style into three main categories. Those categories are sensory preferences, cognitive style, and personality types. Of three categories, the researcher identified that SPR tended to acquire information in sensory preferences. It consists of visual, auditory, and motor modalities / kinaesthetic (Leaver : 2005). visual and kinaesthetic revealed as SPR's preferences in his way to process the information.

A student in visual style like to read and obtain a great deal from visual stimulation, he acquires new knowledge primarily through sight. In this study SPR preferred to learn by using chart or diagram, he used organizational format outlining for recording notes. He would easily to understand his lesson after it was highlighted. Pritchard (2009: 44) stated that a visual student has good visual recall and prefer information to be presented visually, in the form of diagrams, graphs, posters and displays.

Kinesthetics like lots of movement and prefer to learn by doing. In this style, SPR preferred to learn when he directly visiting the place that discusses. He seeks for real live example. He tended to do some experiment and he would better understand if he practiced all of the knowledge that he had already got. He would love to study in this group. By actively participating in discussions, he could directly apply what he had learned about. 
100| ELT Worldwide Vol. 3 No.l April 2016

All of the SPR's ways in learning in line with Pritchard (2009:45) that stated kinesthetic enjoy physical activity, manipulating objects and other practical.

\section{Contributing factors in SPR's learning activities}

The successful of learning activities particularly in language learning is influenced by several factors.

Personality has become one factor that was important in SPR's learning process. It contributed to the level of success SPR achieved throughout his career. A number of theories hold that personality factors significantly influence the degree of success that individuals achieve in learning a second language (Gass \& Selinker : 1994, Cook: 1996, LarsenFreeman \& Long :1991).

SPR's personality was important as it distinguished him from other individuals. Personality development helped him to live with a positive attitude towards life and reduced stress. In general terms of personality, it is divided into extrovert and introvert personality. The findings of this study showed that from SPR was the extrovert person. It was indicated that he was more interested in what is happening around him.

Motivation is one of the important aspects of second language acquisition. It is very difficult to teach a second language in a learning environment if the learner does not have a desire to learn a language. Take into consideration from that aspect, to be able to make the learner active and desirable in learning process gains importance.

SPR desire to learn English was based on his willing to open the business in tourism. He believed that English was one of the most important things in that business. By knowing English, it would support him in running the business.

English practicing, it referred to the experiences and SPR's habits in using English. SPR's experiences and his habits in using English also give impact to his proficiency in his study. According to instructional design expert Seels (1997), Practice is the most important ingredient of effective instruction; it speeds up learning, aids long-term retention, and facilitates recall. Furthermore for developing many of the capacities required for effective occupational practice, experiences in practice settings likely have the potential to make many important contributions that simply cannot be afforded by experiences in educational institutions (Billet, 2010: 24). 
Sampelolo, Atmowardoyo : Learning Strategies and Styles of ... $\mid 101$

Social interaction is also contributed to this students success. It referred to the process by which SPR acted and reacted to those around him, included those actions SPR performed toward each other and the responses they give in return. The social context of SPR was a factor in determining the success or otherwise of study.

As Lund (2003: 61) states that the skills of interacting with others precede both the comprehension and production of words or language. His way in interacted with each other had become one factor that support his learning activities. An important aspect of such social contexts is that they provide rules and expectations about appropriate and inappropriate behavior (Nelson and Jones, 2006:3).

Vygotsky (1978) considers that social interaction is a fundamental aspect of successful cognitive and intellectual growth. Vygotsky (1962) examined how our social environments influence the learning process.

It means that SPR learned through his interactions and communications with others. When he has free time, he would involve himself to joint and make some conversations with his friends. Conversation, sharing, being in touch with others who have active, involved lives gave living a purpose. As Nelson and Jones (2006:2) point out that connection is the essential characteristic of relationships.

The last phenomena related to contributing factors that the researcher found was self-management. Self-management referred to SPR's skill in managing himself. The word management is a key term in understanding successful learners. Student self-manage or control the factors influencing their learning (Dembo 2004: 4). Self-management is considered pivotal to the development of other skills (Koegel: 2006).

In this study, it was revealed that SPR's self-management consisted of two parts. It includes time and lesson management. Time management was related to his ability in managing his time or his schedule both on campus and workplace. Tracey (2004: 670) believed that time management is the art and science of using time prudently and well to achieve personal, professional, career, and organizational goals and objectives. It is the practical and effective system of taking the time to save time so that one can do more of the things that have to be done and have time left over to do some of the things one wants to do. It involves a systematic approach to the management of programs, projects, activities, priorities, and schedules.

During this study, the researcher found that SPR went working every day. While his schedule for his campus from Monday to Friday. 
102| ELT Worldwide Vol. 3 No.1 April 2016

For normal students, it was difficult to do the same activities at the same time, in order to avoid colliding schedule, SPR would adjust his college, he would move to another class for the same lectures. By moving to another class, he would have much more time to do another activity. $\mathrm{He}$ also came on time to ensure optimum learning and working. The skill to manage the time was a must for SPR because the sufficiently high level of his activities.

Lesson management referred to SPR's behavior in managing his lesson. SPR in his free time, or before joining the class, always prepared the lesson for the next. He always carried out his task seriously thus as a consequence that he was never late to entry the task.

Doing task at the workplace, Study after working and Study in the morning was also activities that SPR did. As a busy student, he had to utilize the time he had to get the knowledge or to finish his task. When he had free time in the workplace he would read some books.

By reading a lot, he would comprehend the new information or even new vocabulary, particularly if he read the English book. He would also finish his task in his workplace if he had some changes. After working and coming home he would spend his time for a while to learn his lesson.

\section{Conclusion}

Based on the research findings and the researchers finally concludes that:

1. The student applied direct and indirect strategies in his learning activities.

2. This student is a visual and kinesthetic learner.

3. The factors that contribute to SPR's success are:
a. Personality
b. Motivation
c. English practicing
d. Social interaction
e. Self-management

\section{Suggestions}

1. It is suggested for the learners to employ various learning strategies and recognize learning styles in language learning in order to be getting improvement in all English skills and to optimize gaining the knowledge.

2. The learners are suggested to pay attention to the contributing factors in English language learning. 
Sampelolo, Atmowardoyo : Learning Strategies and Styles of ...|103

\section{REFERENCES}

Anderson, G., and Arsenault, N. (1998) fundamentals of educational research ( $2^{\text {nd }}$ Edition). London: Routledge Falmer.

Brown, D. H. 2002. Strategies for Success: A Practical Guide to Learn English. San Francisco State University: Longman.

Brown, D. H. 2000. Principles of Language Teaching and Learning, $\left(4^{\text {th }}\right.$ Edition). White Plains, NY: Longman.

Beeching, K. 2002. Gender, Politeness and Pragmatic Particles in French. Philadelphia: John Benjamin's Publishing Company.

Billett. S. 2010. Learning through Practice, Models, Traditions Orientation, and Approaches. University of Regensburg: Springer.

Carol J.B.1981.Twenty-Five Years of Research on Foreign Language Aptitude. (Online)

(http://www.jstor.org/stable/.Downloaded $\quad$ on $7^{\text {th }}$ of November 2014).

Calero H. 2005. The Power of Nonverbal Communication. Los Angeles: Silver lake publishing.

Celce, M. 2001. Teaching English as a Second or Foreign Language. $\left(3^{\text {rd }}\right.$ Edition). NY: Dewey Publishing Services.

Collier, V. P. 1988. The Effect of Age on Acquisition of a Second Language for School. New Focus. The National Clearinghouse for Bilingual Education. No: 2, Winter: 19871988.

Cook, V. 1996. Second language learning and teaching (2 ${ }^{\text {nd }}$ Edition.). New

York:Arnold.(Online)(http://g6a55.mail.163.com/a/f/js3/080129 0924/htmltool_js3_v1.htm second language . Downloaded on $7^{\text {th }}$ of November 2014).

Dembo, H. M. 2004. Motivation and Learning Strategies for College Success ( $2^{\text {nd }}$ Edition). California: University of southern.

Dunlap Z. C. \& Weisman M. E. 2007. Helping English Language Learners Succeed. $\quad$ U.S.A.: Huntington Beach. 
104| ELT Worldwide Vol. 3 No.1 April 2016

Dunlap C. Z. \& Weisman, M. E. 2006. Helping English Language Learners Succeed. U.S.A: Huntington Beach.

Gardner, H. 1999. Intelligence Reframed: Multiple Intelligences for the $21^{\text {st }}$ Century. New York: Basic Books.

Gass, S., \& Selinker, L. 1994. Second Language Acquisition: an Introductory Course. Hillsdale, NJ: Lawrence Erlbaum.

Gardner, H. 1993. Multiple Intelligences: The Theory in Practice. New York: Basic Books.

Haryanto. 1999. Motivation and Learning Strategy of Good EFL Learner, Unpublished dissertation. Jakarta: IKIP Jakarta.

Hannell, G. 2008. Success with Inclusion: 1001 Teaching Strategies and Activities that Really Work. UK and Canada: Routledge.

Hewitt D. 2008. Understanding Effective Learning Strategies for the Classroom. London: Open University Press.

Joseph, R. 2009. Learning Strategy. The University of Kansas Center for Research on Learning. (Online) (Http://pdri.kucrl.org Downloaded on $9^{\text {th }}$ of October 2014)

Johnstone, B. 1994. Repetition in Discourse: A Dialogue”. Repetition in Discourse: Interdisciplinary Perspectives, Norwood, NJ: Ablex.

Leaver, L. B., Ehrman M, \& Shekhatman B, 2005. Achieving Success in Second Language Acquisition. New York: Cambridge University Press.

Larsen-Freeman, D., \& Long, M. 1991. An Introduction to Second Language Acquisition Research. London: Longman.

Lund N. 2003. Language and Thought. London: Routledge.

Mahdavy B. 2008. The Role of Multiple Intelligences (MI) in Listening Proficiency:A Comparison of TOEFL and IELTS Listening Tests from an MI Perspective. The Asian EFL Journal Quarterly September. 2008,10 (3): 109 - 126.

Macintyre, P. D., \& Gardner, R. C. 1994a. The Subtle Effects of Language Anxiety on Cognitive Processing In the Second Language. Language Learning. International Journal of Bilingualism'. 2007, 11 (4) 391-409. 
Sampelolo, Atmowardoyo : Learning Strategies and Styles of ... $\mid 105$

Nelson R. \& Jones. 2006. Human Relationship Skills: Coaching and Self-Coaching. $\left(4^{\text {th }}\right.$ Edition).USA: Routledge.

Nikolov M. 2009. Early Learning of Modern Foreign Languages Processes and Outcomes. Great Britain: Short Run Press Ltd.

Oxford, R. 1990. Language Learning Strategies: What Every Teacher Should Know. Boston: Heinle and Heinle.

Pritchard A. 2009. Ways of Learning: Learning Theory and Learning Style in the Classroom ( $2^{\text {nd }}$ Edition). London: Routledge.

Pritchard A. and Woollard J. 2010. Psychology for the classroom: constructivism and social learning. London: Routledge.

Reid G. 2005. Learning Style and Inclusion. Wiltshire Great Britain: Cromwell Press.

Reid, G., and Strnadova. I. 2004. The Development of Teacher and Student Measures for Identifying learning Styles. Pilot research study, the University of Edinburgh in collaboration with Charles Universit: Prague

Richard C. J. \& Schmidt R. 2002. Language Teaching and Apply Linguistics. ( $3^{\text {rd }}$ Edition). New York: Longman

Rubin, J. 1975. What The Good Language Learner Can Teach Us. TESOL Quarterly. 9(2): 41-51.

Rubin, J. 1987. Learner Strategies: Theoretical Assumptions, Research History and Typology. In Wenden \& J. Rubin (Eds.), Learner Strategies in Language Learning. Englewood, NJ: Prentice/Hall International.

Sepehri Z. 2013. Effect of Personality on Learning Language. ICT for language learning $\quad\left(6^{\text {th }}\right.$ Edition). (Online).(http:/www.businessballs.com/ personality styles models.HTML downloaded on $12^{\text {th }}$ November 2014).

Seels, B. \& Glasgow, Z. 1997. Making Instructional Design Decisions ( $2^{\text {nd }}$ Edition). Upper Saddle River, NJ: Prentice Hall.

Seo M.G., Barrett, L. F., \& Bartunek, J. M. 2004. The Role of Affective Experience in Work Motivation. Academy of management.

Sheen. Y. 2008. Recasts, Language Anxiety, Modified Output, and L2 Learning. University of Michigan: Language Learning Research Club. 
106| ELT Worldwide Vol. 3 No.1 April 2016

Tracey, W. R. 2004. The Human Resources Glossary: the Complete Desk Reference for Hr Executives, Managers, and Practitioners. $\left(3^{\text {rd }}\right.$ Edition). US: ST. Lucie press.

Ushioda E. \& Griffiths, C. (Eds.) 2008. Lessons from Good Language Learners. Lessons from Good Language Learners. Cambridge: Cambridge University Press.

Vygotsky, L.S. 1986. Thought and Language. Cambridge, MA: MIT Press.

Vygotsky, L. 1978. Mind in Society. Cambridge, MA: Harvard University Press.

Weda, S. 2005. English Learning Strategies Employed By Senior Secondary Scholl Students. Unpublished dissertation, Makassar: PPS-UNHAS Makassar.

Willis, J. 2008. How Your Child Learns Best. U.S.A: Sourcebooks, Inc.

Zhang Y. 2008. The Role of Personality in Second Language Acquisition. Qingdao University of Science and Technology, Qingdao: China. (Online)(Http// www.ccsenetorg/journal html, downloaded on $8^{\text {th }}$ of October 2014). 